\title{
First Trimester Renin and Aldosterone Levels of Pregnant Women With Prognosis of Preeclampsia and/or Related Adverse Pregnancy Outcomes
}

\author{
Yunus Emre Purut, ${ }^{1}$ Ayşe Yasemin Karageyim Karşıdağ, ${ }^{2}$ \\ Esra Esim Büyükbayrak, ${ }^{3}$ Asuman Orçun, ${ }^{4}$ Mehmet Menke ${ }^{4}$
}

$$
\begin{array}{r}
\text { 'Department of Obstet \& Gynecol, } \\
\text { Boyabat 75. Year Hospital, } \\
\text { Sinop, Turkey } \\
\text { 'Department of Health Sciences, } \\
\text { Kırklareli University, Kırklareli, } \\
\text { Turkey }
\end{array}
$$

${ }^{3}$ Department of Obstet \& Gynecol, Marmara University Pendik Training and Research Hospital, İstanbul, Turkey

${ }^{4}$ Department of Biochemistry, Kartal Dr. Lütfi Kırdar Training and Research Hospital, İstanbul, Türkiye

Submitted: 24.05 .2016 Accepted: 20.09.2016

Correspondence: Ayşe Yasemin Karageyim Karşıdağ, Kozyatağı Mah., Avşar Sok., 46/10 Kadıköy, İstanbul, Turkey

E-mail: ykarageyim@yahoo.com

口isto

Keywords: Aldosterone; preeclampsia; poor obstetric prognosis; renin.

\begin{abstract}
Objective: To evaluate the first-trimester renin and aldosterone levels in pregnancies complicated by prognosis of preeclampsia and/or related adverse pregnancy outcomes.

Methods: We measured serum levels of renin and aldosterone in pregnant women for first trimester screening test. Total of 180 pregnant women were included in the study and I44 of them completed the study. All pregnant women were followed during pregnancy for preeclampsia and related complications. Renin and aldosterone levels in preeclampsia and/ or poor obstetric prognosis group were compared with normal pregnancy outcome group.

Results: Preeclampsia developed in 13 pregnant women and one or more poor obstetric outcome developed in 36 women. Renin and aldosterone levels were not significantly different in preeclamptic women or those with poor obstetric outcome compared with the controls.
\end{abstract}

Conclusion: We think that maternal first trimester renin and aldosterone levels do not have a role in the pathogenesis and prediction of preeclampsia.

\section{INTRODUCTION}

Hypertensive conditions which develop related to pregnancy bring with them both maternal, and fetal risks. The most important of maternal risks is eclamptic crisis, while fetal risks include poor obstetric prognosis as intrauterine growth retardation (IUGG) developed due to decreased placental perfusion. ${ }^{[1]}$ Gestational hypertension and preeclampsia are multisystemic diseases, and they regress af- ter birth. However their pathophysiologies have not been elucidated yet. Renin aldesteron system provides sodium balance, blode pressure and volume regulation during pregnancy. ${ }^{[2,3]}$ Renin-aldosterone system is stimulated with pregnancy, and demonstrates marked changes when compared with non-pregnants. ${ }^{[2,4]}$

The role of renin-aldosterone system in preeclampsia, and IUGG has been investigated in many studies, and contradictory results have been reported. Increased, unchanged 
or even decreased levels of renin, and aldosterone have been reported in cases with preeclampsia, and IUGG. [1,3,5-11] Studies usually have evaluated renin, and aldosterone during second, and third trimesters, while in very few studies their levels were measured during first trimester. [3] These differences in the literature may stem from differences in methods or timing ( $\mathrm{I}^{\text {st }}, 2^{\text {nd }}$ or $3^{\text {rd }}$ trimester) measurements.

In this prospective study, we aimed to evaluate the correlation between renin, aldosterone levels measured during the first trimester with preeclampsia, and poor pregnancy prognosis, and its role in the prediction of preeclampsia.

\section{MATERIAL AND METHODS}

This prospective study was performed in perinatology polyclinics of our hospital between February 2014, and February 2015. Local ethic comitte approval and written informed constent forms of the patients were obtained. For the first trimester screening tests blood samples were drawn between II., and 14. gestational weeks to measure renin, and aldosterone levels. The patients who stated that they will attend follow-up visits in our clinic were included in our study in order of their times of application. The patients with medical problems as chronic hypertension, diabetes mellitus, endocrinologic disease, and chronic renal disease, those with high risk based on double test results, pregnants with congenital anomalies, and multiparas were not included in the study Among a total of 180 pregnant participants only 144 patients completed the study.

Fasting state blood samples were obtained from the patients who applied for the first trimester screening tests. Blood samples were collected in dry gel-filled tubes.To prevent erroneous results due to fibrin formation, and hemolysis, the tubes were awaited for 30 minutes for clot forming. Then the sample was centrifuged for 10 minutes at $4000 \mathrm{rpm}$. Blood samples were transferred into EDTA containing tubes to obtain plasma portion, and promptly tubes were centrifuged at $4000 \mathrm{rpm}$ for 10 minutes. Aldosterone was analyzed in serum, and renin in plasma portions of the samples transferred into Eppendorf tubes, and kept under $-80^{\circ} \mathrm{C}$ till the day of analysis. For measurements, serum, and plasma samples stored at -80 were brought into room temperature for their thawing. The thawed samples were homogenized in a mixer, and renin levels were measured using DIAsource renin EASIA kit (DIAsource immunoassays S.A Belgium). The sensitivity of the kit was specified as $3.9 \mathrm{pg} / \mathrm{ml}$. Intraassay CV (Coefficients of Variability) for $67.3 \mathrm{pg} / \mathrm{ml}$ was $2.2 \%$, and interassay $\mathrm{CV}$ for $64.6 \mathrm{pg} / \mathrm{ml}$ was indicated as 3.3 percent.

Aldosterone was measured using sandwich ELISA method with DiaMetra Aldosteron ELISA kit (DiaMetra R\&D and manufacturing Perrugia/ITALY). The sensitivity of the kit was specified as $7 \mathrm{pg} / \mathrm{ml}$. Its intraassay, and interassay $\mathrm{CVs}$ were $<9.7 \%$ and $<11 \%$, respectively.

Ultrasonographic screening of all pregnant women were performed by the same perinatologist using the same equipment (General Electric, Voluson E6, Austria $\mathrm{GmbH}$ \& Co OG abdominal convex probe 2-7 MHz, RAB6-D), and pregnant women were followed up till birth. Type of delivery, gestational week, and birth weight of newborns were recorded.

Fetal death, preeclampsia, gestational hypertension (nonproteinüric hypertension developed during pregnancy), low-birth-weight baby (SGA - birth weight that is below the 10 . percentile for gestational age), and preterm birth (birth at $<34$ gestational week) were considered as poor obstetric prognosis. Generalized edema proteinuria $(\geq 300$ $\mathrm{mg} / 24 \mathrm{hr}$ ), and hypertension (>140/90 $\mathrm{nmHg}$ ) developed unrelated to a renal disease after 20. gestational week were accepted as the criteria for preeclampsia.

For statistical analysis of the study results, IBM SPSS Statistics 22 (IBM SPSS, Turkey) program was used. Fitness of parametres to normal distribution was evaluated using Shapiro-Wilk normality test. Study data were evaluated using descriptive statistical methods (mean, standard deviation, and frequency), for intergroup comparisons of parametres with normal distribution Student $t$ test, for those without normal distribution Mann-Whitney $U$ test were used. Statistical significance was evaluated at a level of $\mathrm{p}<0.05$.

\section{RESULTS}

Hundred and eighty consecutive patients who consulted perinatology clinic of our hospital for double test, and volunteered to participate in the study were included in our study. During follow-up of the patients, pregnants whose probable risk of chromosomal anomaly were greater than I/370 between II., and 14. gestational weeks were excluded from the study Besides, patients with morbid obesity, chronic hypertensive disease, preexisting renal proteinuria, and those lost to follow-up were excluded from the study. Thus our study was completed with 144 patients.

All patients were followed up during entire course of their pregnancies. During monitorization of the patients, 13 patients were diagnosed as preeclampsia. In our study group, preeclampsia was seen in nearly $9 \%$ of the patients. Gestational hypertension developed in 3 patients, also preterm labour $(n=6)$, intrauterine growth retardation $(n=12)$, and oligohydramnios $(n=7)$, and intrauterine fetal death were detected $(n=5)$. Other complications included development of gestational thrombocytopenia $(n=2)$, and gestational cholestasis $(n=I)$. In conclusion, in 36 patients one or more than one unfavourable obstetric outcome developed. 
Table I. Clinical and biochemical characteristics of the patients

\begin{tabular}{|c|c|c|}
\hline & Min-Max & Mean $\pm S D$ \\
\hline Maternal age (years) & $18-40$ & $29.15 \pm 4.90$ \\
\hline Gestational age (wks) & $21-42$ & $38.49 \pm 2.31$ \\
\hline Birth weight (gr) & $550-4900$ & $3297.52 \pm 533.74$ \\
\hline $\operatorname{Renin}(p g / m l)$ & $1-106.2$ & $40.08 \pm 15.68$ \\
\hline Aldosterone (pg/ml) & $7.67-1998.6$ & $246.35 \pm 221.83$ \\
\hline \multicolumn{3}{|l|}{ Fetal gender } \\
\hline Male & 73 & 50.7 \\
\hline Female & 70 & 48.6 \\
\hline Ex fetus (ambiguous) & I & 0.7 \\
\hline \multicolumn{3}{|l|}{ Parity } \\
\hline Nullipara & 33 & 22.9 \\
\hline Primipara/multipara & III & 77.1 \\
\hline
\end{tabular}

SD: Standard deviation.

Clinical characteristics of the cases are summarized in Table I. Complications developed in study participants included preterm labour $(n=6 ; 4.2 \%)$, intrauterine growth retardation $(n=12 ; 8.3 \%)$, and intrauterine fetal death $(n=5 ; 3.5 \%)$. Majority $(n=128 ; 88.95 \%)$ of the cases were normotensive, while preeclampsia $(n=13 ; 9 \%)$, and gestational hypertension $(n=3 ; 2.1 \%)$ were detected in respective number of patients. Sixteen percent of the cases were smokers. In our study preeclampsia recurred in 4 (57.1\%) of 7 cases with a history of preeclampsia.

Any statistically significant intergroup difference was not detected between the cases with unfavourable, and favourable obstetric outcomes regarding renin, and aldosterone levels (Table 2). In pregnants who developed preeclampsia, and gestational hypertension, renin, and aldosterone levels were much lower but without any statistically significant difference.

\section{DISCUSSION}

Multiple number of biomarkers have been investigated during the first trimester of pregnancy as predictive factors in pregnancy-induced hypertension, and especially preeclampsia which is one of the predominant causes of maternal, and fetal morbidity, and mortality. Renin - aldosterone system has been held responsible from the underlying pathophysiology of these diseases. ${ }^{[\mid-1]]}$

Activated renin concentration slightly increases in the first trimester of the pregnancy, and at 20. gestational week reaches up to 5 -fold higher levels compared to baseline,

Table 2. Evaluation of poor obstetric history, maternal renin, and aldosterone levels

\begin{tabular}{|c|c|c|c|c|}
\hline & $\begin{array}{l}\text { Renin Levels } \\
\text { (Mean士SD) }\end{array}$ & $\underset{P^{\prime}}{\text { Renin }}$ & $\begin{array}{l}\text { Aldosteron Levels } \\
\text { (Mean } \pm \text { SD) }\end{array}$ & $\begin{array}{c}\text { Aldosterone } \\
\mathbf{P}^{2}\end{array}$ \\
\hline \multicolumn{5}{|l|}{ Preeclampsia } \\
\hline Present $(n=13)$ & $41.79 \pm 9.28$ & 0.529 & $412.21 \pm 515.19$ & 0.235 \\
\hline Absent $(n=|3|)$ & $39.91 \pm 16.2$ & & $229.89 \pm 163.11$ & \\
\hline \multicolumn{5}{|l|}{ Hypertensive disease } \\
\hline Present $(n=16)$ & $43.4 \pm 11.53$ & 0.372 & $373.76 \pm 468.78$ & 0.291 \\
\hline Absent $(n=128)$ & $39.67 \pm 16.12$ & & $230.42 \pm 164.78$ & \\
\hline \multicolumn{5}{|l|}{ Preterm Labour } \\
\hline Present $(n=6)$ & $43.2 \pm 8.02$ & 0.620 & $189.94 \pm 117.08$ & 0.572 \\
\hline Absent $(n=138)$ & $39.95 \pm 15.94$ & & $248.8 \pm 225.21$ & \\
\hline \multicolumn{5}{|c|}{ Small for gestational age } \\
\hline Present $(n=12)$ & $39.53 \pm 16.36$ & 0.900 & $203.36 \pm 148.08$ & 0.603 \\
\hline Absent $(n=132)$ & $40.13 \pm 15.68$ & & $250.26 \pm 227.36$ & \\
\hline \multicolumn{5}{|c|}{ Intrauterine fetal death } \\
\hline Present $(n=5)$ & $47.61 \pm 16.45$ & 0.276 & $|4| .3 \mid \pm 90.27$ & 0.167 \\
\hline Absent $(n=139)$ & $39.81 \pm 15.65$ & & $250.13 \pm 224.37$ & \\
\hline \multicolumn{5}{|c|}{ Poor obstetric prognosis } \\
\hline Present $(n=36)$ & $40.84 \pm 14.05$ & 0.737 & $260.7 I \pm 33.07$ & 0.417 \\
\hline Absent $(n=108)$ & $39.83 \pm 16.25$ & & $241.56 \pm 168.85$ & \\
\hline
\end{tabular}

'Student t-test; ${ }^{2}$ Mann-Whitney U test; SD: Standard deviation. 
then draws a plateau. ${ }^{[12]}$ In various studies renin, and aldosterone levels were found to be lower in preeclamptic women than those of normotensive pregnants. ${ }^{[3,4]}$ Lewis et al. reported that renin-aldosterone system is effected by impaired production of vasodilatory prostaglandins. [13] Lower maternal plasma renin levels reflect increased vasoconstriction in gestational hypertension. ${ }^{[1]}$ In both normotensive, and hypertensive pregnants renin-renin aldosterone system is effected by placental estrogen, and progesterone, and induces pregnancy-related physiologic variations both in blood pressure, and blood volume..$^{[1,11]}$

In the literature, some publications indicated that in normotensive pregnants plasma renin activity increases, while in hypertensive pregnants it does not change..$^{[1,3]}$ However August et al. detected that renin levels in superimposed eclampsia decrease in the third trimester which they related this outcome to defective increase in estradiol levels in the third trimester. ${ }^{[3]}$ In conclusion, they interpreted their study outcomes as "changes in renin levels are not the cause but the result, and they occur in the third trimester". [3] In preeclamptic pregnants, more prominent decreases were detected in the third trimester rather than the first trimester. ${ }^{[3,14]}$ In our study in compliance with these anferomentioned results, we could not have found difference between plasma renin levels measured in the first trimester of normotensive, and hypertensive pregnants. Since we planned our study for prediction of preeclampsia, we did not measure renin levels in the second, and third trimesters which is one of the limitations of our study. Different techniques used to measure renin levels, effects of bed rest, and sodium intake on renin levels in blood samples have been held responsible from controversial results cited in the literature. ${ }^{[I]}$

In our study a statistically significant difference was not found between maternal plasma renin levels, and fetal complications including growth intrauterine retardationon and these results are similiar with the literature. ${ }^{[1,15]}$ Renin does not enter into fetal circulation thus prorenin, rather than renin plays a role in the regulation of fetal development. ${ }^{[16]}$

Plasma aldosterone level increases progressively starting from the early gestational period..$^{[1,12]}$ On $16^{\text {th }}$ gestational week, it rises up to $40 \mathrm{ng} / \mathrm{dl}$, and at 32. gestational week it increases up to $60 \mathrm{ng} / \mathrm{dl}$, and it is responsible for increase in plasma volume. ${ }^{[12]}$ This increase is partly due to increases in renin activity, and partly decreases in enhanced antialdosteronic effect of increased progesterone. ${ }^{[2]}$ In various studies, maternal serum aldosterone levels were detected to be higher in all three trimesters in pregnants when compared with non-pregnants, while aldosterone levels were lower in all three trimesters in pregnants who developed preeclampsia relative to normotensive pregnants. ${ }^{[1,3,4]}$ In our study first-trimester maternal serum aldosterone levels were not statistically significantly different between hypertensive, and normotensive pregnants. The serum aldosterone levels were measured during early gestational weeks in our study and this condition might lead to our different outcomes from the literature. So it is the second limitation of our study.

Based on literature findings, and our study results, reninaldosterone system seems to involve in the outcomes of gestational hypertensive disease, and related complications, rather than their pathogenesis. Though these markers do not play a role in the development of hypertension, they might speed up or worsen the process.

Authorship contributions

Concept: Y.E.P., A.Y.K.K.; Design: Y.E.P., A.Y.K.K.; Data collection \&/or processing: Y.E.P., A.Y.K.K.; Analysis and/ or interpretation: M.M, A.O.; References search: Y.E.P., A.Y.K.K.; Writing: A.Y.K.K.; Critical review: E.E.B.

Conflict of interest

None declared.

\section{REFERENCES}

1. Elsheikh A, Creatsas G, Mastorakos G, Milingos S, Loutradis D, Michalas $\mathrm{S}$. The renin-aldosterone system during normal and hypertensive pregnancy. Arch Gynecol Obstet 2001;264:182-5. [CrossRef]

2. Easterling TR, Benedetti TJ, Schmucker BC, Millard SP. Maternal hemodynamics in normal and preeclamptic pregnancies: a longitudinal study. Obstet Gynecol 1990;76:1061-9.

3. August P, Lenz T, Ales KL, Druzin ML, Edersheim TG, Hutson $\mathrm{JM}$, et al. Longitudinal study of the renin-angiotensin-aldosterone system in hypertensive pregnant women: deviations related to the development of superimposed preeclampsia. Am J Obstet Gynecol 1990;163(5 Pt 1):1612-21. [CrossRef]

4. Brown MA, Nicholson E, Gallery ED. Sodium-renin-aldosterone relations in normal and hypertensive pregnancy. Br J Obstet Gynaecol 1988;95:1237-46. [CrossRef]

5. Tapia HR, Johnson CH, Strong CG. Renin angiotensin system in normal and hypertensive disease of pregnancy. Lancet 1972;2:84753. [CrossRef]

6. Brenner T, Evron S, Soffer D, Abramsky O. Treatment of experimental allergic encephalomyelitis in rabbits with alpha-fetoprotein. Isr J Med Sci 1985;21:945-9.

7. Skinner SL, Lumbers ER, Symonds EM. Analysis of changes in the renin angiotensin system during pregnancy. Clin Sci 1972;42:47983. [CrossRef]

8. Kalenga MK, Thomas K, de Gasparo M, De Hertogh R. Determination of renin, angiotensin converting enzyme and angiotensin II levels in human placenta, chorion and amnion from women with pregnancy induced hypertension. Clin Endocrinol (Oxf) 1996;44:429-33.

9. Ferraris P, Quorso P, Gazzano G, Cianci M, Sala C, Turolo L, et al. Plasma active and inactive renin and fetal complications in women with high risk pregnancies. Can J Physiol Pharmacol 1991;69:13216. [CrossRef]

10. Kingdom JC, McQueen J, Connell JM, Whittle MJ. Fetal angiotensin 
II levels and vascular (type I) angiotensin receptors in pregnancies complicated by intrauterine growth retardation. Br J Obstet Gynaecol 1993;100:476-82. [CrossRef]

11. Gökcan B, Laçin S, Atmaca F, Gürbüz A, Cantekin D. Renin and proren in levels in sera of pregnancies complicated with severe preeclampsia and lugr. Perinatoloji Dergisi 1999;7:36-9.

12. Wilson M, Morganti AA, Zervoudakis I, Letcher RI, Romns BM, Von Oeyon P, et al. Blood pressure, the renin-aldosterone system and sex steroids throughout normal pregnancy. Am J Med 1980;68:97104. [CrossRef]
13. Lewis PJ, Boylan P, Friedman LA, Hensby CN, Downing I. Prostacyclin in pregnancy. Br Med J 1980;280:1581-2. [CrossRef]

14. Langer B, Grima M, Coquard C, Bader AM, Schlaeder G, Imbs JL. Plasma active renin, angiotensin I, and angiotensin II during pregnancy and in preeclampsia. Obstet Gynecol 1998;91:196-202. [CrossRef]

15. Ferraris P, Quorso P, Gazzano G, Cianci M, Sala C, Turolo L, et al. Plasma active and inactive renin and fetal complications in women with high risk pregnancies. Can J Physiol Pharmacol 1991;69:1321-6.

16. Lenz T. Prorenin and active renin in human fetal circulation. Acta Obstet Gynecol Scand 1996;75:291-3. [CrossRef]

\section{Preeklampsi ve Ilişkili Kötü Obstetrik Prognoz Gelişen Gebelerde Birinci Trimester Renin ve Aldosteron Düzeyleri}

Amaç: Preeklampsi ve ilişkili kötü obstetrik prognoz gelişen gebelerde birinci trimester renin ve aldosteron düzeylerini belirlemek.

Gereç ve Yöntem: Birinci trimester taraması için kan veren gebelerde renin ve aldosteron düzeylerine bakıldı. Çalışmaya $I 80$ hasta alındı, hastalardan I44'ü çalışmayı tamamladı. Gebeler doğuma kadar preeklampsi ve kötü obstetrik prognoz gelişimi için izlendi. Preeklampsi ve kötü obstetrik prognoz gelişen gebelerin sonuçları normal gebelik seyri olan grupla karşılaştırıldı.

Bulgular: Hastaların I3'ünde preeklampsi, 36'sında ise bir veya daha fazla kötü obstetrik sonuç gelişti. Peeklampsi ve kötü obstetrik sonuç gelişen olgular ile gelişmeyen olguların renin ve aldosteron düzeyleri karşılaştırıldığında istatistiksel olarak anlamlı bir fark saptanmadı.

Sonuç: Birinci trimester renin ve aldosteron düzeylerinin preeklampsi etiyolojisi ve öngörüsünde yeri olmadığını düşünmekteyiz.

Anahtar Sözcükler: Aldosteron; kötü obstetrik prognoz; preeklampsi; renin. 